\title{
PENGEMBANGAN BUKU BERBASIS MULTI REPRESENTASI SERI FLUIDA DENGAN PENDEKATAN SAINS TEKNOLOGI DAN MASYARAKAT (STM)
}

\author{
Kristin S Silaban*), Fauzi Bakri, Mutia Delina \\ Program Studi Pendidikan Fisika, Fakultas Matematika dan Ilmu Pengetahuan Alam. Universitas Negeri Jakarta, Jl. \\ Pemuda Rawamangun No.10 Jakarta Timur, 13220. \\ Email: ${ }^{1}$ kristin.silaban38@gmail.com
}

\begin{abstract}
Abstrak
Kami telah mengembangkan sebuah buku berbasis multi representasi untuk materi Fluida dengan menggunakan pendekatan Sains Teknologi dan Masyarakat (STM). Materi dalam buku ini disajikan dalam bentuk verbal, matematis, grafik, dan tabel. Buku seri Fluida disajikan dari tingkat pengetahuan yang rendah sampai pengetahuan tinggi. Metode penelitian yang digunakan adalah Model Pengembangan Instruksional (MPI) oleh Atwi Suparman dengan model pendekatan Educational research and development yang terdiri atas 9 tahapan. Telah dilakukan uji keterbacaan terhadap 5 orang siswa dengan hasil komponen materi tercapai $81,25 \%$, komponen tata bahasa $80 \%$, dan kelengkapan penyajian $82,5 \%$. Buku ini telah divalidasi oleh tim ahli materi dan media, dan pembelajaran. Dengan hasil porsentasi kelayakan materi $80,19 \%$, media $78,91 \%$, dan pembelajaran 90,28 \%. Dari hasil validasi dan uji coba tersebut diperoleh interpretasi sangat baik, maka pengembangan buku materi fluida berbasis multirepresentasi ini layak digunakan untuk menjadi buku referensi.
\end{abstract}

Kata Kunci: penelitian pengembangan, buku multirepresentasi, Fluida

\section{Abstract}

We have developed a multi-representative book for Fluids using Science Technology and Society approach. The content of this book represents in verbal, mathematic, graphic, and table forms. Fluids series book presented from basic knowledge to advanced knowledge. Research method that applied is Instructional Development Model (IDM) by Atwi Suparman with Educational research and development approach model consist of 9 stages. Legibility test has done to 5 students with result of content reach 81,25\%, language 80\%, and presentation $82,5 \%$. This book has validated by content, media, and instructional expert team. The percentage result of proper content 80,19\%, media 78,91\%, and instructional 90,28\%. From the validation result and test obtain very good interpretation, so that development of multi-representative book for fluids can be used to be reference book.

Keywords: research development, multi-representative book, Fluids

\section{PENDAHULUAN}

Komponen sistem pembelajaran yaitu terdiri dari peserta didik, proses pembelajaran, dan lulusan dengan kompetensi yang diharapkan, pengajar, kurikulum dan bahan pembelajaran) .[1] Seperti yang disebutkan kurikulum mengambil peran penting dalam kegiatan pembelajaran siswa. Sesuai dengan kurikulum yang berlaku yaitu Kurikulum 2013 dinyatakan adanya 5 kegiatan belajar yaitu: mengamati, menanya, mengumpulkan informasi, mengasosiasi dan mengkomunikasikan. Guru bertindak sebagai fasilitator sehingga siswa dituntut untuk lebih aktif dalam belajar. Siswa perlu menggali pengetahuan dengan memanfaatkan media dan sumber belajar. Dengan media pembelajaran, siswa dapat mengalami secara langsung tentang pengetahuan baru yang disampaikan oleh guru .[2] Beberapa media pembelajaran yang sering digunakan yaitu modul, LKS (Lembar Kerja Siswa) dan buku. 
Buku merupakan sumber belajar. Dikatakan bahwa buku berperan penting dan strategis dalam upaya meningkatkan mutu pendidikan[3]. Menurut Survey UNESCO 2012 minat membaca siswa terhadap buku yang ada sangat minim, mengatakan kecenderungan atau kesadaran seseorang untuk melakukan suatu aktivitas komunikasi karena adanya perhatian dan perasaan tertarik atau senang dengan tujuan untuk mengetahui isi buku Fisika Hal ini juga didukung karena dari segi tata bahasa buku yang susah diterima siswa dan tampilan yang hanya menampilkan konsep teks, soal dan gambar pendukung.

Komponen penilaian buku meliputi empat komponen, dijelaskan dalam rincian beriku [4]:

- Kelayakan isi

- Kebahasaan

Komponen kebahasaan diuraikan dengan indikator berikut:

a. Keterbacaan,

b. Kesesuaian dengan kaidah bahasa Indonesia yang baik dan benar,

c. Logika berbahasa.

- Penyajian

Komponen penyajian diuraikan dengan indikator berikut:
a. Teknik,
b. Materi,
c. Pembelajaran

- Kegrafikan

Komponen kegrafikan diuraikan dengan indikator berikut:
a. Ukuran/format buku
b. Desain bagian kulit,
c. Desain bagian isi
d. Kualitas kertas,
e. Kualitas cetakan,
f. Kualitas jilidan.

Dalam kegiatan observasi yang dilakukan oleh peneliti sendiri, peneliti menganalisis representasi dari buku fisika kelas $\mathrm{X}$ yang disusun oleh Joko Sumarno tahun 2009, peneliti mendapat hasil bahwa representasi yang ditampilkan buku meliputi urutan yang kurang sistematis dimana pada salah satu buku pada halaman pertama diberikan tugas proyek yang kurang berhubungan dengan materi yang akan dibahas, belum menampilkan apersepsi sebagai pengetahuan awal serta tidak semua bab disertai dengan aplikasi dalam kehidupan sehari-hari dan buku fisika kelas XI yang disusun oleh Marteen Kanginan dengan tahun terbit 2006 soal yang disajikan cenderung sulit untuk di selesaikan, belum menampilkan bentuk grafik atau tabel data.

Hal tersebut menjadikan perlunya suatu media yang dapat mengembangkan /potensi diri dan rasa ingin tau siswa terhadap apa yang telah dipelajari siswa. Media yang diperlukan yaitu berupa media belajar berbentuk buku cetak yang menampilkan materi dengan tingkatan pengetahuan dasar sampai tingkat pengetahuan tinggi dengan menyajikan suatu konsep dengan data berbentuk grafik, gambar, persamaan matematika dan aplikasi dalam kehidupan sehari-hari sebagai penambah pengetahuan siswa yaitu dalam tampilan multi representasi [5] Multi representasi dapat membantu pembelajar dalam mempelajari dan membangun suatu konsep dan mengatasi permasalahan, membantu dalam memecahkan masalah, serta membantu untuk menyikapi masalah terutama yang berkaitan dengan aplikasi pelajaran fisika yang berhubungan dengan sains dan masyarakat [6]

Berpijak pada uraian di atas, maka diperlukan suatu pengembangan bahan ajar fisika berupa buku berbasis multi representasi dengan seri Fluida yang sesuai dengan pendekatan Sains Teknologi dan Masyarakat.

\section{METODE PENELITIAN}

Model penelitian pengembangan instruksional yang digunakan dalam penelitian ini adalah model pengembangan instraksional yang dikembangkan oleh Atwi Suparman (2014 : 130) yang dimodifikasi dari model pendekatan Educational research and development Walter Dick dan Lou Carey.[7] Berikut alur model penelitiannya:

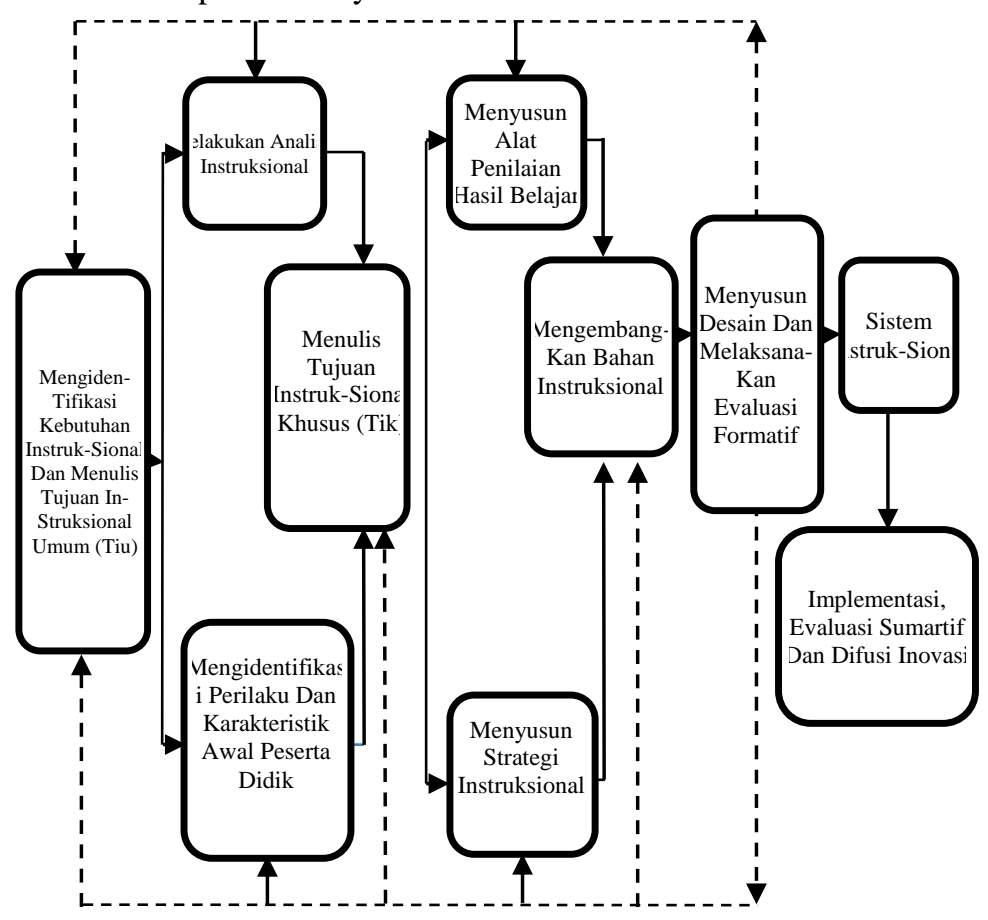

Gambar 1. Model Pengembangan Instruksional Dick and Carey dalam Atwi, 2014:130)

Teknik pengumpulan data yang digunakan berupa kuesioner. Kuesioner ini akan diisi setelah responden mengamati produk terlebih dahulu. Kuesioner ini menggunakan rating scale. Responden pada penelitian ini, yaitu: Ahli materi dan media berasal dari Dosen Fisika FMIPA UNJ, 


\section{HASIL DAN PEMBAHASAN}

\section{Buku berbasis multi representasi}

Hasil penelitian ini berupa buku berbasis multi representasi pada materi fluida dengan pendekatan sains teknologi dan masyarakat. Buku ini terdiri dari 4 bab yaitu Pendahuluan Fluida, Fluida Statis, Fluida Dinamis, dan Aplikasi Fluida dalam kesehatan dan Teknologi.

Sesuai model pendekatan yang digunakan maka materi pada isi buku mengacu pada peta konsep dan disajikan dalam Tujuan Instruksional Khusus. Pada awal bab akan berikan ilustrasi gambar dan penjelasan materi yang akan dibahas. Terdapat "sains masyarakat" pada awal bab yang menyajikan contoh kecil permasalahan dan aplikasi pada subbab yang akan dibahas. Seperti tampilan gambar dibawah

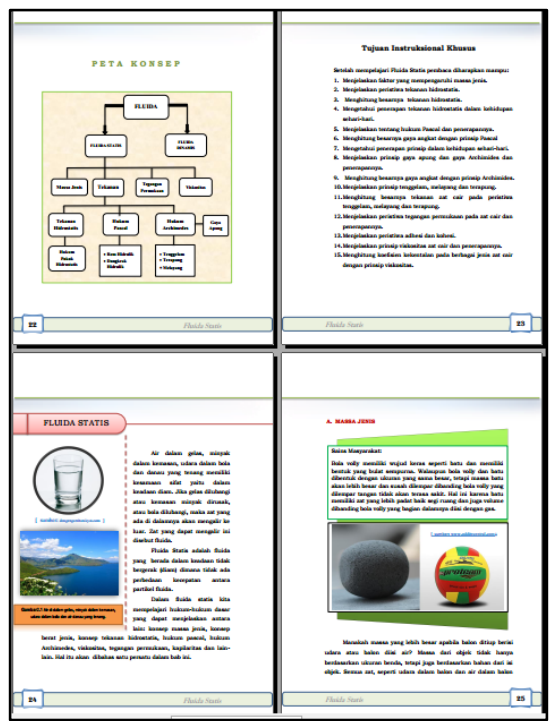

Gambar 2. Tampilan awal buku terdapat peta konsep, Tujuan Instruksional Khusus dan Sains Masyarakat.

\footnotetext{
Buku referensi disajikan berbasis multirepresentasi. Menurut prndekatan multirepresentasi adalah pendekatan yang menggunakan berbagai bahasa sains dalam pembelajaran , seperti kata (oral dan menulis), visual (gambar, grafik, simulasi) simbol dan persamaan, gerak-gerik tubuh, bermain peran, presentasi dan lain lain.[8]. Pada beberapa materi di dalam buku disajikan dalam berbagai representasi seperti contoh: massa jenis, pada materi ini disajikan data percobaan dalam tabel, dan didukung dengan adanya gambar dan penjelasan verbal ditampilkan dalam sajian grafik sehingga didapat persamaan matematisnya. Seperti gambar berikut.
}

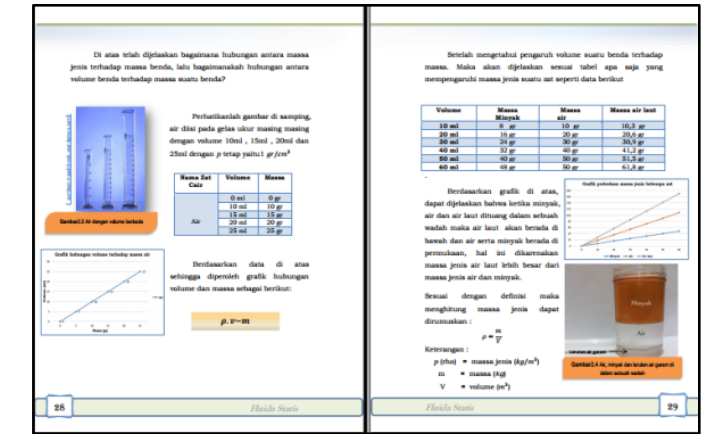

Gambar 3. Tampilan multi representasi buku pada materi massa jenis

Buku referensi menggunakan pendekatan Sains Teknologi Masyarakat. Dimana pendekatan tersebut dalam pandangan sosial dan humaniora, pada dasarnya memberikan pemahaman tentang kaitan antara sains teknologi dan msyarakat, melatih kepekaan penilaian peserta didik terhadap dampak lingkungan sebagai akibat perkembangan sains dan teknologi.[9] Sehingga dalam buku contoh yang digunakan berkaitan dengan teknologi dan kehidupan sehari-hari seperti tampilan berikut.

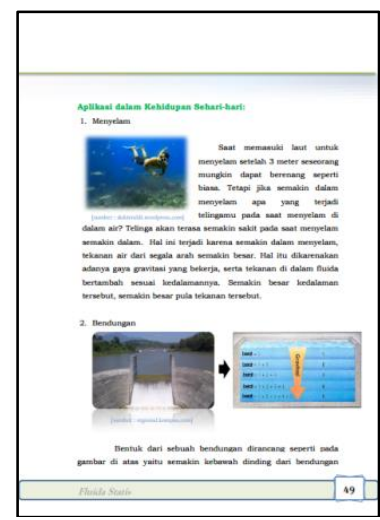

Gambar 4. Tampilan isi buku tentang aplikasi Fluida dalam kehidupan sehari-hari.

Buku referensi disajikan dari pengetahuan yang dasar sampai tingkat tinggi dimulai dengan apersepsi sampai beberapa contoh kasus. Pada akhir buku akan diberikan rangkuman dari bab yang telah dipelajari.

\section{Uji Kelayakan}

Buku berbasis multi representasi seri Fluida ini telah divalidasi oleh ahli materi, ahli media dan ahli pembelajaran. Penilaian dan saran dari ahli akan menjadi bahan pertimbangan untuk merevisi dan memperbaiki buku "Buku Multi Representasi FLUIDA" sehingga produk yang dihasilkan memiliki kualitas yang lebih baik lagi. Adapun hasil skor untuk masingmasing sub komponen oleh para penguji disajikan pada pada tabel berikut:

Untuk uji materi terdapat 38 butir pertanyaan yang dicakup dalam 3 sub komponen. 
Tabel 1. Aspek yang diuji oleh ahli materi

\begin{tabular}{|c|l|}
\hline No & \multicolumn{1}{|c|}{ Aspek } \\
\hline 1 & Kesesuaian Materi Fluida \\
\hline 2 & Teknik Penyajian Materi Fluida \\
\hline 3 & Tata Bahasa dan Penulisan \\
\hline
\end{tabular}

Berdasarkan aspek di atas sehingga didapat hasil seperti gambar berikut.

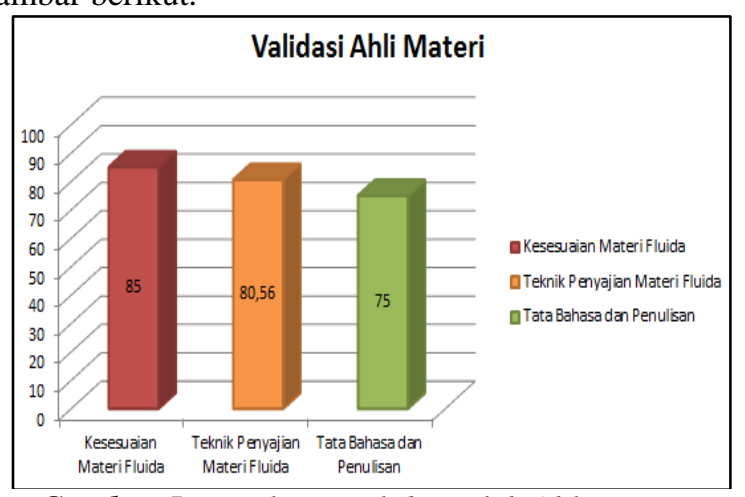

Gambar 5. Hasil Uji Validasi oleh Ahli Materi.

Untuk uji materi terdapat 23 butir pertanyaan yang dicakup dalam 7 sub komponen.

Tabel 2. Aspek yang diuji oleh ahli media

\begin{tabular}{|c|l|}
\hline No & \multicolumn{1}{|c|}{ Aspek } \\
\hline 1 & Fisik Buku \\
\hline 2 & Tata Letak Cover pada Buku Fluida \\
\hline 3 & Tata Letak Isi Buku \\
\hline 4 & Grafika Tabel dan Grafik \\
\hline 5 & Ilustrasi dalam Buku Fluida \\
\hline 6 & $\begin{array}{l}\text { Grafika Penulisan Huruf, Rumus dan } \\
\text { Simbol }\end{array}$ \\
\hline 7 & Komponen Buku \\
\hline
\end{tabular}

Berdasarkan aspek di atas sehingga didapat hasil seperti gambar berikut.

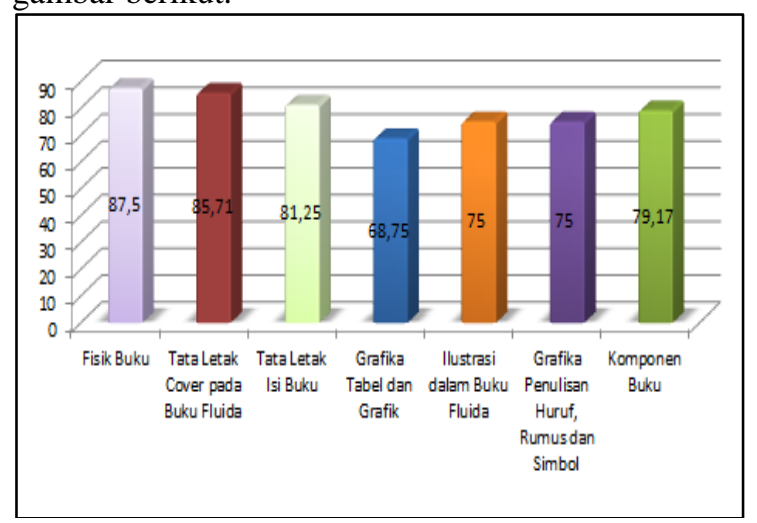

Gambar 6. Hasil Uji Validasi oleh Ahli Media

Untuk uji materi terdapat 15 butir pertanyaan yang dicakup dalam 2 sub komponen.
Tabel 3. Aspek yang diuji oleh ahli pembelajaran

\begin{tabular}{|c|l|}
\hline No & \multicolumn{1}{|c|}{ Aspek } \\
\hline 1 & $\begin{array}{l}\text { Kebutuhan komponen Pendekatan Sains } \\
\text { Teknologi Masyarakat (STM) }\end{array}$ \\
\hline 2 & $\begin{array}{l}\text { Penerapan Pendekatan Sains Teknologi } \\
\text { Masyarakat pada Buku Fluida }\end{array}$ \\
\hline
\end{tabular}

Berdasarkan aspek di atas sehingga didapat hasil seperti gambar berikut.

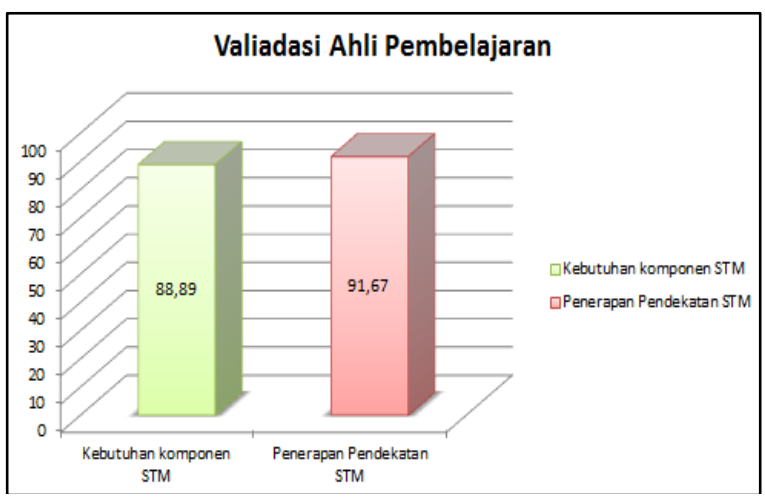

Data yang diperoleh dianalisis dengan melakukan perhitungan menggunakan skala Likert. Instrumen yang digunakan menggunakan skala Likert dengan pilihan skor 1-5.[10]

$1=$ tidak bagus / tidak jelas

2 = kurang bagus / kurang jelas

3 = cukup bagus / cukup jelas

4 = bagus / jelas

5 = sangat bagus / sangat jelas

Batas penilaian ketepatan dan kesesuaian

Pengembangan Bahan Ajar untuk dijadikan sebagai alat bantu pembelajaran didasarkan pada kriteria interpretasi skor untuk skala Likert, yaitu:

$$
\begin{array}{ll}
0-20 \% & \text { : sangat kurang baik } \\
21-40 \% & \text { : kurang } \\
41-60 \% & \text { : cukup } \\
61-80 \% & \text { : baik } \\
81-100 \% & \text { : sangat baik }
\end{array}
$$

Interpretasi skor dihitung berdasarkan skor perolehan tiap item:

$$
\% \text { Interpretasi Skor }=\frac{\Sigma \text { skor perolehan }}{\Sigma \text { skor maksimum }} \times 100 \%
$$

Tabel 5. Hasil rata-rata interpretasi skor ahli

\begin{tabular}{|l|c|}
\hline \multicolumn{1}{|c|}{ Aspek } & \% Interpretasi \\
\hline Ahli Materi & $80.19 \%$ \\
\hline Ahli Media & $78.91 \%$ \\
\hline Ahli Pembelajaran & $90.28 \%$ \\
\hline
\end{tabular}

Tabel di atas menunjukkan interpretasi skor rata-rata dari tiap ahli dengan aspek media bernilai baik dan untuk materi serta pembelajaran bernilai sangat baik dan “ Buku Multi representasi FLUIDA' dinyatakan layak sebagai buku referensi. 


\section{PENUTUP}

Berdasarkan hasil penelitian yang telah dilakukan, maka dapat disimpulkan bahwa buku berbasis multirepresentasi dapat dijadikan sebagai buku referensi untuk mempelajari materi Fluida.

Berdasarkan proses penelitian dan hasil penelitian, maka peneliti memberikan saran untuk melakukan peneletian lanjutan terhadap buku berbasis multirepresentasi untuk materi lainnya. Selain itu, peneliti juga menyarankan agar buku berbasis multirepresentasi yang sudah ada dikembangkan dengan seri Mekanika secara lengkap.

Peneliti mengucapkan terima kasih terhadap pih ak Universitas Negeri Jakarta (UNJ), para dosen serta pihak yang telah membantu dan mendukung jalannya penelitian ini.

\section{DAFTAR PUSTAKA}

[1] Atwi Suparman, M. (2012) Desain Instruksional Modern. Jakarta: Erlangga.

[2] Arif S, Sadiman,dkk (2003). Media pendidikan: Pengembangan dan Pemanfaatannya. Jakarta PT.Grafindo Pesada

[3] Permendiknas, 2008: 2

[4] Tarigan,H.G.Telaah Buku teks bahasa Indonesia: Bandung: Angkasa 1989

[5] Lasry, N. \& Aulls, M.W. 2007. The effect of multiple internal representation on context-rich instruction. Americans Journal of Physics, 75

[6] Irwandani. Multi Representasi Sebagai Alternatif Pembelajaran Dalam Fisika. 2014. Vol 3: hal.

[7] Atwi Suparman, M. (2012) Desain Instruksional Modern. Jakarta: Erlangga.

[8] Waldrip, B. V. Prain dan Carolan. (2007). "Learning Junior Secondary Science through Multi-Modal Representations" dalam Electronic Journal of science Education Preview Publication.Vol.11, No1.

[9] Anna Poedjiadi. 2005.Sains Teknologi Masyarakat.Bandung: PT.Remaja. Rosda Karya.

[10] Sugiyono. (2010).Metode Penelitian Kuantitatif Kualitatif dan $R \& D$. Bandung: Alfabet. 
